\title{
A Nerve Terminal Protein with a Selective Distribution in Spinal Cord and Brain
}

\author{
Teresa C. Ritchie, Mitchell A. Thomas, and Joe D. Coulter \\ Department of Anatomy, College of Medicine, The University of lowa, lowa City, lowa 52242
}

A monoclonal antibody, designated S-7B8, recognizes a protein antigen localized to highly selecied populations of nerve terminals in spinal cord and brain. The antibody produces dense immunocytochemical staining of primary afferent endings that synapse in superficial laminae of the spinal cord dorsal horn. Electron microscopy shows staining to be localized in nerve terminals where reaction product is associated primarily with spherical vesicles. In brain, S-7B8 immunoreactivity occurs in nerve terminals in sensory relay nuclei, most thalamic nuclei, and other selected areas, including the cerebellar molecular layer, the substantia nigra, the globus pallidus, and certain synaptic layers of the hippocampus and dentate gyrus. Endocrine glands and other tissues do not exhibit S-7B8 immunoreactivity. Although the antibody localizes to certain populations of nerve terminals that may use excitatory amino acid neurotransmitters, the distribution of S-7B8 immunoreactivity in the CNS does not correspond to that of any previously identified nerve terminal protein.

Experiments to characterize the S-7B8 antigen indicate it may be an integral membrane component since extraction of synaptosomes with alkaline $\mathrm{pH}$ or high ionic strength does not release the antigen from the membranes. To identify the molecular weight of the S-7B8 antigen, synaptosomal membranes were solubilized in CHAPS and sequentially chromatographed on hydroxylapatite and then on DEAE anion-exchange resin to produce enriched fractions. When enriched fractions were separated on SDS-PAGE and Western blotted, the S-7B8 antibody specifically stained a protein migrating at 75,000 $\mathrm{Da}$. This protein has been designated NT75.

Preliminary studies of developing pathways show that the appearance of S-7B8 immunoreactivity in growing nerve endings corresponds closely to the time when synaptic connections are formed. Thus, the NT75 protein recognized by the S-7B8 antibody may have a role in the development and maintenance of specific synaptic endings.

\footnotetext{
Received Nov. 16, 1988; revised Jan. 19, 1989; accepted Jan. 20, 1989.

We wish to thank Shami Kanekar, David Wright, LeAnne Cabalka, and Tami Thomas; the Central Electron Microscope Facility of The University of Iowa, in particular Cheryl Olson; and the Hybridoma Facility of The University of lowa, for participation and advice in some experiments. This work was supported by NIH grants NS23379 (formerly NS12481) and NS23783.

Correspondence should be addressed to Teresa C. Ritchie, Ph.D., at the above address.
}

Copyright (C) 1989 Society for Neuroscience $0270-6474 / 89 / 082697-13 \$ 02.00 / 0$
Nerve terminals contain the specialized organelles and constituent proteins involved in the secretion of neurotransmitters and in the maintenance of the presynaptic membrane and synaptic contact. In this respect the protein composition of nerve terminals differs substantially from that of the rest of the cell, although it is generally accepted that proteins destined for nerve terminals are axonally transported from their site of synthesis in the nerve cell body. As far as the protein composition of nerve terminals is known, it appears that the great majority of these proteins are common to all nerve terminals. Proteins involved in various aspects of the secretory process, including routing of synaptic vesicles, docking and fusion of vesicles with the plasma membrane, and vesicle retrieval and recycling, seem likely to be shared by most neurons (see Kelly and Hooper, 1982; Kelly et al., 1983; Smith and Augustine, 1988). Several of the constituent proteins of synaptic vesicle membranes have been recently identified (Matthew et al., 1981; Huttner et al., 1983; Buckley and Kelly, 1985; Jahn et al., 1985; Wiedenmann and Franke, 1985). They have widespread distributions in central and peripheral nerve terminals, and, in certain instances, are components of secretory vesicles of non-neuronal cells.

In contrast to nerve terminal proteins that have widespread distributions, a small number of identified proteins are limited to selected populations of nerve endings. Perhaps the best characterized are those associated with specific neurotransmitters. These include dopamine- $\beta$-hydroxylase in noradrenergic nerve terminals (Axelrod and Kopin, 1969; Swanson and Hartman, 1975), choline acetyltransferase in cholinergic nerve terminals (Wainer et al., 1984), and the secretogranins in peptidergic nerve endings (Kennedy, 1985; Rosa et al., 1985). Furthermore, components of various second-messenger systems, which mediate effects on neurotransmitter release through protein phosphorylation, are known constituents of nerve terminals and have been found to be selectively distributed (Ouimet et al., 1984; Miller, 1985; Worley et al., 1986a, b).

Selectively distributed nerve terminal proteins have also been implicated in various aspects of axonal growth, guidance, recognition, and cell-to-cell adhesion (Sperry, 1963; Thiery et al., 1977; Sanes et al., 1978; Gottlieb and Glaser, 1980; Schachner et al., 1983; Dodd et al., 1984; Schwob and Gottlieb, 1988). Examples of this class include the growth-associated proteins, or GAPS (for review, see Benowitz and Routtenberg, 1987), proteins associated with nerve growth cones (Ellis et al., 1985; Wallis et al., 1985), and recently described proteins associated with electromotor nerve terminals, including agrin (Magill-Solc and McMahan, 1988) and the nerve terminal anchorage protein, TAP-1 (Carlson et al., 1986). 
This report describes studies that have led to the identification of a nerve terminal protein with a restricted and unique distribution in spinal cord and brain. A monoclonal antibody, designated S-7B8, was developed using brain synaptosomes as immunogen. This antibody localizes to selected populations of nerve terminals where immunocytochemical staining is mainly associated with synaptic vesicles. Experiments to characterize the S-7B8 antigen indicate that it is a membrane protein with a molecular weight of approximately 75,000 Da. Preliminary studies in developing nervous system suggest that this antigen may have a role in the formation and maintenance of specific populations of synaptic endings. Portions of this work have been reported previously in abstract form (Kanekar et al., 1986; Ritchie et al., 1986b, c; Wright et al., 1986).

\section{Materials and Methods}

\section{Materials}

Hydroxylapatite (Bio-Gel HT) was purchased from Bio-Rad and DEAESepharose CL-6B from Pharmacia. 3-[(3-cholamidopropyl)dimethylammonio]-1-propansulfonate (CHAPS) and ultrapure Tris were obtained from Boehringer Mannheim. Trypsin (Type XIII) and soybean trypsin inhibitor (Type I-S) were purchased from Sigma. Nitrocellulose paper was purchased from Millipore $(0.45 \mu \mathrm{m})$ or Schleicher and Schuell $(0.2 \mu \mathrm{m}$; BA83). Acrylamide, electrophoresis grade, was obtained from Eastman Kodak Company, and other electrophoresis reagents and standards were purchased from Bio-Rad. Immunochemical reagents were obtained from Cooper Biomedical (goat anti-mouse IgG, with no crossreactivity to rat IgG; peroxidase-conjugated goat anti-mouse IgG), Sternberger-Meyer (mouse peroxidase-antiperoxidase), or Jackson Immunochemicals (purified nonimmune mouse $\mathrm{IgG}$ ).

\section{Neuronal membrane preparations}

Synaptosomes were prepared from whole rat brain by a modification of the method of Gurd et al. (1974), as described previously (Ritchie et al., 1985). Rat brain particulate fractions were prepared by centrifugation $(160,000 \times g \times 2 \mathrm{hr})$ of the postnuclear supernatant. Membrane pellets were lyophilized and stored at $-70^{\circ} \mathrm{C}$.

\section{Monoclonal antibodies}

Monoclonal antibodies to rat brain synaptosomes were prepared by conventional somatic cell hybridization methods (Kennett et al., 1978). Details of the immunization, and the monoclonal antibody production and screening methods have been described previously (Ritchie et al., 1986a). Twenty-one clones were selected, expanded, and subcloned by limiting dilution. This report presents studies using the antibody $\left(\mathrm{IgG}_{1}\right.$ subclass) secreted by the S-7B8 cell line. A monoclonal antibody to synaptophysin (SY 38), a $M_{r} 38,000$ synaptic vesicle protein (Wiedenmann and Franke, 1985), was purchased from Boehringer Mannheim Biochemicals.

\section{Immunocytochemistry}

Light microscopy. Rats were deeply anesthetized and perfused with saline followed by freshly prepared $3.5-4.0 \%$ paraformaldehyde in 50 $\mathrm{mm}$ phosphate buffer, $\mathrm{pH} 7.4$. Frozen sections $(20-40 \mu \mathrm{m})$ of spinal cord, brain, and other tissues were stained with S-7B8 antibody from ascitic fluid (diluted $1 / 1000-1 / 20,000$ ) or culture supernatant (diluted $1 / 1-1 / 10$ ) using the peroxidase-antiperoxidase (PAP) method of Sternberger (1978). Details of the immunocytochemical staining procedure have been described elsewhere (Ritchie et al., 1985, 1986a). Controls consisted of omitting S-7B8 antibody from the overnight incubation solution or using ascitic fluid from the parent myeloma cell line or purified nonimmune mouse IgG as primary antibodies. No staining was observed on control sections.

To determine the origins of stained terminals in the superficial dorsal horn of the spinal cord, unilateral dorsal rhizotomies were performed ( 4 animals). Three to 6 consecutive lumbosacral dorsal roots were sectioned, and survival times of 6-14 d were used. In a second group of 4 animals, gel foam pads soaked in colchicine $(20 \mathrm{mg} / \mathrm{ml})$ were applied to lumbar dorsal root ganglia L4-L6. After $16-48 \mathrm{hr}$, the animals were perfused and immunocytochemical staining was carried out as described.

Electron microscopy. The staining in the spinal cord produced by the S-7B8 antibody was localized at the ultrastructural level by preembedding immunocytochemistry with the PAP method (Pickel et al., 1975; Ruda et al., 1982). The fixative solution was $4.0 \%$ paraformaldehyde and $0.05-0.1 \%$ glutaraldehyde in $50 \mathrm{~mm}$ phosphate buffer, $\mathrm{pH} 7.4$. Immunocytochemical staining of $50 \mu \mathrm{m}$ vibratome sections was similar to that employed for light microscopy with the exception that detergents werc omitted from all solutions. Following immunocytochemical staining, sections were postfixed in buffered $2.0 \%$ glutaraldehyde for $30-60$ $\mathrm{min}$, then in $1.0 \%$ osmium tetroxide for $1 \mathrm{hr}$, dehydrated with ethanol, and embedded in Spurr's resin. Thin sections (100-120 nm) were prepared from the surface of the vibratome sections and were viewed and photographed without counterstaining in a Hitachi H-600 electron microscope.

\section{Dot immunobinding assay}

Quantitative analysis of the S-7B8 antigen in various subcellular and protein fractions from rat brain was carried out using a dot-immunobinding assay. Initially, the protocol supplied with the Bio-Dot apparatus was followed (Bio-Rad). In later experiments, the procedure was modified to facilitate the binding of proteins in detergent solution to the nitrocellulose paper. Samples were diluted in PBS and $0.5-5 \mu \mathrm{g}$ protein was applied to each well. On each assay, synaptosome standards were spotted at $0.1-10 \mu \mathrm{g} /$ well. For detergent-containing samples, proteins were precipitated onto the nitrocellulose paper with $50 \mu \mathrm{l}$ of $20 \%$ trichloroacetic acid (TCA) for $1 \mathrm{~min}$; the solution was then drawn through the membrane and rinsed once with PBS. The membrane was then removed from the apparatus and dried. One set of samples was stained for total protein with aniline blue/black, while a duplicate set for staining with antibodies was incubated with 5\% nonfat dry milk in PBS (BLOTTO) (Johnson et al., 1984). Immunostaining was accomplished using an indirect peroxidase method with antibodies diluted in BLOTTO, and the peroxidase reaction was carried out as described previously (Ritchie et al., 1986a). The assays were analyzed with a scanning densitometer and the specific activity (antigen units $/ \mu \mathrm{g}$ protein) of experimental fractions was determined by comparison with the synaptosome standards. By definition, 1.0 antigen unit corresponds to the S-7B8 immunoreactivity in $1.0 \mu \mathrm{g}$ of brain synaptosomes on the assay system. The S-7B8 specific activity of synaptosomes is thus 1.0 (1.0 antigen unit/ $\mu \mathrm{g}$ protein).

\section{Chromatography on hydroxylapatite}

An "alkaline-stripped" neuronal membrane preparation was used as starting material for column chromatography. "Alkaline-stripped" membranes were prepared by homogenizing lyophilized synaptosomes

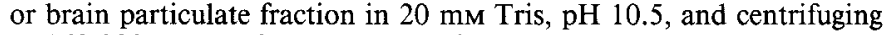
at $160,000 \times g \times 2 \mathrm{hr}$. The resulting membrane pellet was then lyophilized and stored at $-70^{\circ} \mathrm{C}$ until used. For chromatography, alkalinestripped membranes were homogenized in $75 \mathrm{~mm}$ sodium phosphate buffer, pH 7.2 (PB), containing $16 \mathrm{~mm}$ CHAPS and protease inhibitors $(10 \mu \mathrm{g} / \mathrm{ml}$ aprotinin, $1 \mu \mathrm{g} / \mathrm{ml}$ leupeptin, $2 \mu \mathrm{g} / \mathrm{ml}$ antipain, $10 \mu \mathrm{g} / \mathrm{ml}$ benzamidine, $1 \mu \mathrm{g} / \mathrm{ml}$ chymostatin, and $1 \mu \mathrm{g} / \mathrm{ml}$ pepstatin A; Lopez et al., 1985). The CHAPS soluble fraction (supernatant) was obtained after centrifugation at $160,000 \times g$ for $2 \mathrm{hr}$ and applied to a hydroxylapatite column $(1.5 \times 12 \mathrm{~cm})$ equilibrated in $75 \mathrm{~mm}$ PB and $16 \mathrm{~mm}$ CHAPS. The column was washed with equilibration buffer and then bound proteins were eluted with a $110 \mathrm{ml}$ linear gradient of $75-200 \mathrm{~mm}$ sodium phosphate, pH 7.2, containing $16 \mathrm{~mm}$ CHAPS, at a flow rate of $8 \mathrm{ml} /$ $\mathrm{hr}$, and $2 \mathrm{ml}$ fractions were collected. Chromatography was carried out at $4^{\circ} \mathrm{C}$. Gradient fractions containing the S-7B8 antigen were identified on the dot-immunobinding assay and pooled.

\section{Chromatography on DEAE-Sepharose CL-6B}

Pooled hydroxylapatite column fractions containing peak S-7B8 specific activity were applied directly to a $1 \times 7 \mathrm{~cm}$ column of DEAE-Sepharose $\mathrm{CL}-6 \mathrm{~B}$ (flow rate of $20 \mathrm{ml} / \mathrm{hr}$ ) that was equilibrated in $20 \mathrm{~mm}$ Tris-HC buffer, $\mathrm{pH} 8.0$, containing $150 \mathrm{~mm} \mathrm{NaCl}$ and $16 \mathrm{~mm}$ CHAPS (TBS/ CHAPS). The column was washed with TBS/CHAPS and bound proteins were eluted with a $50 \mathrm{ml}$ linear gradient of $150-450 \mathrm{mM} \mathrm{NaCl}$ in TB/CHAPS at a flow rate of $5 \mathrm{ml} / \mathrm{hr}$ and $2 \mathrm{ml}$ fractions were collected. Chromatography was carried out at $4^{\circ} \mathrm{C}$. The S-7B 8 specific activity of 

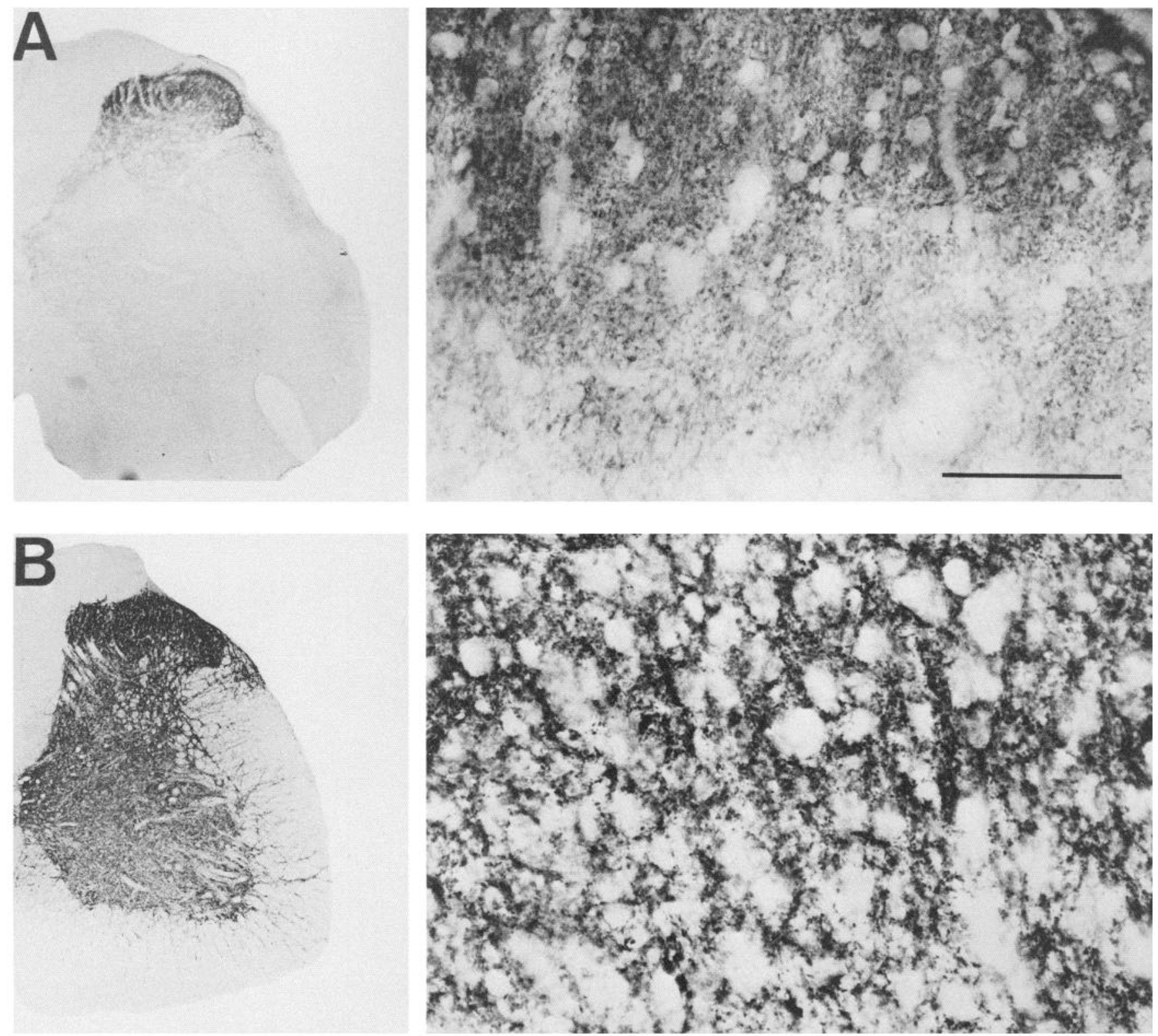

Figure 1. Comparison of staining in the lumbar spinal cord produced by S-7B8 antibody and anti-synaptophysin. $A$, S-7B8 antibody densely stains the superficial dorsal horn. At higher magnification (right panel), there is fine punctate staining of nerve terminals, while cell bodies (clear areas) are unstained. $B$. Anti-synaptophysin produces staining throughout the spinal gray matter, and the dorsal horn (right panel) shows punctate labeling of nerve terminals. Scale bar, $50 \mu \mathrm{m}$.

the gradient fractions was determined on the dot-immunobinding assay. The fractions were then dialyzed overnight against 2 changes of distilled $\mathrm{H}_{2} \mathrm{O}$, lyophilized, and stored at $-70^{\circ} \mathrm{C}$.

\section{SDS-PAGE and immunoblotting}

Protein samples were electrophoresed on $7.5 \%$ acrylamide minigels (BioRad Mini-Protean II apparatus) using the discontinuous buffer system of Laemmli (1970). Proteins were electrophoretically transferred to 0.2 $\mu \mathrm{m}$ nitrocellulose paper, at $100 \mathrm{~V}$ for $70 \mathrm{~min}$ at $4^{\circ} \mathrm{C}$, and stained with antibodies diluted in BLOTTO using an indirect immunoperoxidase method (Towbin et al., 1979).

\section{Protein determination}

Protein was quantified according to a modification of the Lowry method (Lowry et al., 1951; Markwell et al., 1978) or by the Bradford method (Bradford, 1976).

\section{Results}

\section{Immunocytochemistry}

Spinal cord. The pattern of immunocytochemical staining in the rat lumbar spinal cord exhibited by the S-7B8 antibody is illustrated in Figure $1 \mathrm{~A}$. Staining is present in the dorsal horn (laminae I-V) and is densest in the superficial part (laminae I and IIi). This staining consists of punctate granules, suggestive of a localization to nerve terminals (Fig. $1 A$, right panel). Staining in the intermediate gray matter and the ventral horn is sparse. The pattern of staining is similar at all spinal cord levels, with the exception of relatively dense punctate staining in the region of the parasympathetic preganglionic nuclei of sacral spinal segments. Cell bodies do not exhibit staining, and staining in 
Figure 2. A, Immunocytochemical staining of lumbar dorsal horn with the S-7B8 antibody 1 week following unilateral dorsal rhizotomy on the left side. $B$, Colchicine treatment of dorsal root ganglia reveals the presence of S-7B8 immunoreactivity in many ganglion cells. Scale bar, $50 \mu \mathrm{m}$.
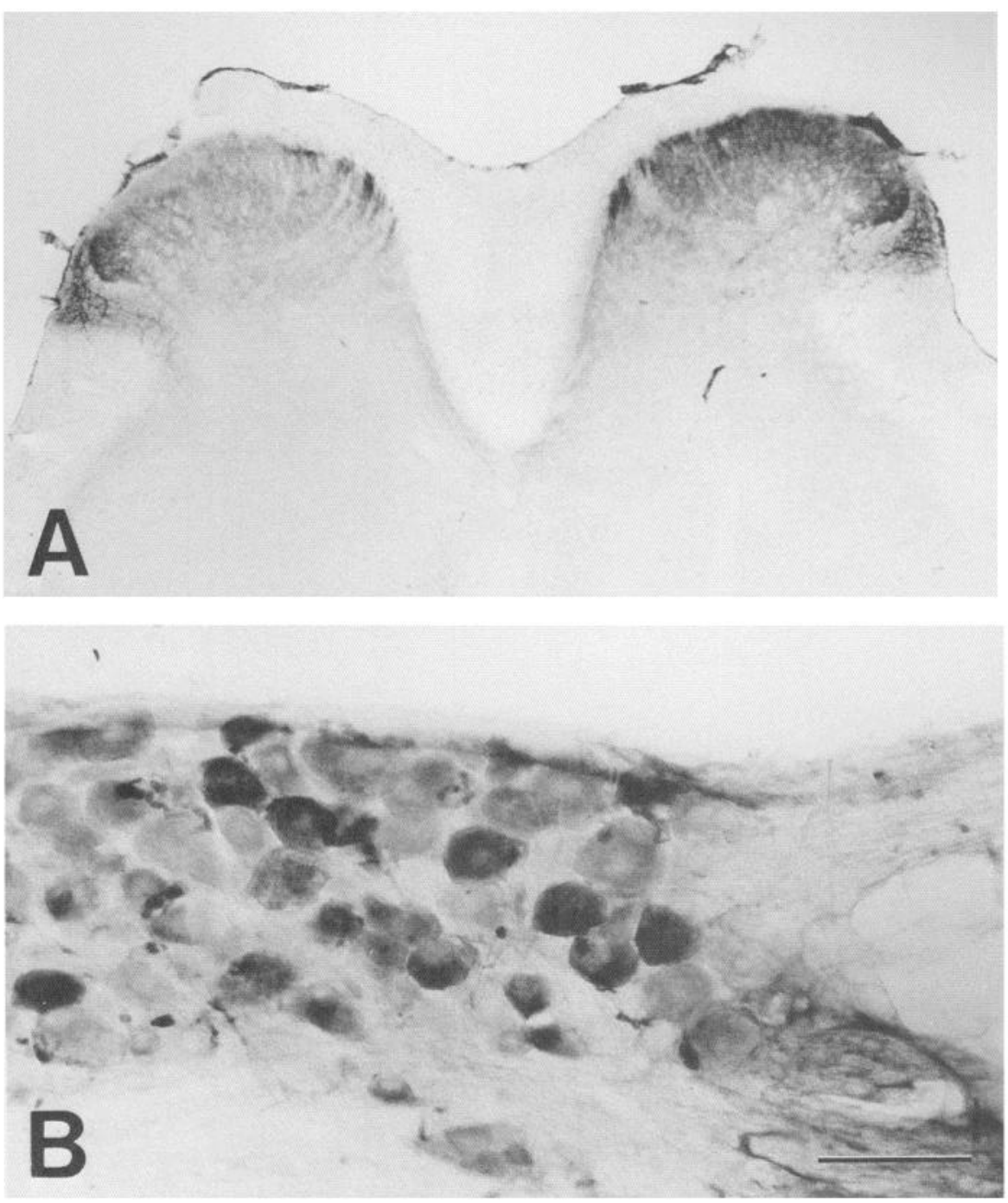

the spinal white matter is restricted to a small area in the dorsal part of the lateral funiculus.

To further illustrate the high degree of selectivity exhibited by the S-7B8 antibody, the staining pattern produced in the spinal cord by anti-synaptophysin is illustrated (Fig. 1B). Anti-synaptophysin staining occurs throughout the spinal gray matter, and the staining appears highly punctate. The staining pattern is consistent with the localization of synaptophysin in synaptic vesicle membranes of virtually all nerve terminals (Jahn et al., 1985; Wiedenmann and Franke, 1985).

Origin of stained nerve terminals. Since the S-7B8 antibody stains nerve terminals concentrated in the dorsal horn, further experiments evaluated whether dorsal root ganglion cells are the source of the labeled terminals. The S-7B8 antibody normally does not stain cell bodies in the dorsal root ganglia. However, application of colchicine to the ganglia to block axonal transport results in the staining of large numbers of small- and mediumsized ganglion cells, and some large-sized ganglion cells (Kanekar et al., 1986) (Fig. 2B). Consistent with these results, sectioning the dorsal roots produces a marked loss of staining in the superficial laminae (I, II) of the dorsal horn (Fig. 2A). Laminae III-V also show a depletion following dorsal rhizotomy, but residual staining is present. These results indicate that pri- mary afferent neurons contribute most of the S-7B8-positive nerve terminals to laminae I and II, and a portion of those to laminae III-V of the spinal cord.

Brain. In the brain, the S-7B8 antibody produces punctate staining of selected populations of nerve terminals (Fig. 3). Cell bodies and most fiber tracts are not stained. S-7B8 immunoreactivity is prominently associated with nerve terminals of sensory pathways, including the terminal fields of all the primary sensory systems and their respective brain-stem relay and thalamic nuclei. A number of other areas also exhibit dense staining, including the cerebellar molecular layer, substantia nigra, globus pallidus, various cerebral cortical areas, and certain synaptic layers of the hippocampus and dentate gyrus (Goodlett et al., 1986; Wright et al., 1986).

Endocrine glands and other tissues. Immunocytochemical staining with the S-7B8 antibody is virtually absent in adrenal gland, thyroid, pituitary, and pancreas (not illustrated). Some sparse punctate staining, which gives the appearance of labeled nerve terminals, occurs in the neural lobe of the pituitary. S-7B8 immunoreactivity is not observed in non-neuronal cells, including liver, glabrous skin, skeletal muscle, or proximal and distal small intestine.

Electron microscopy. As suggested by the light microscopic 

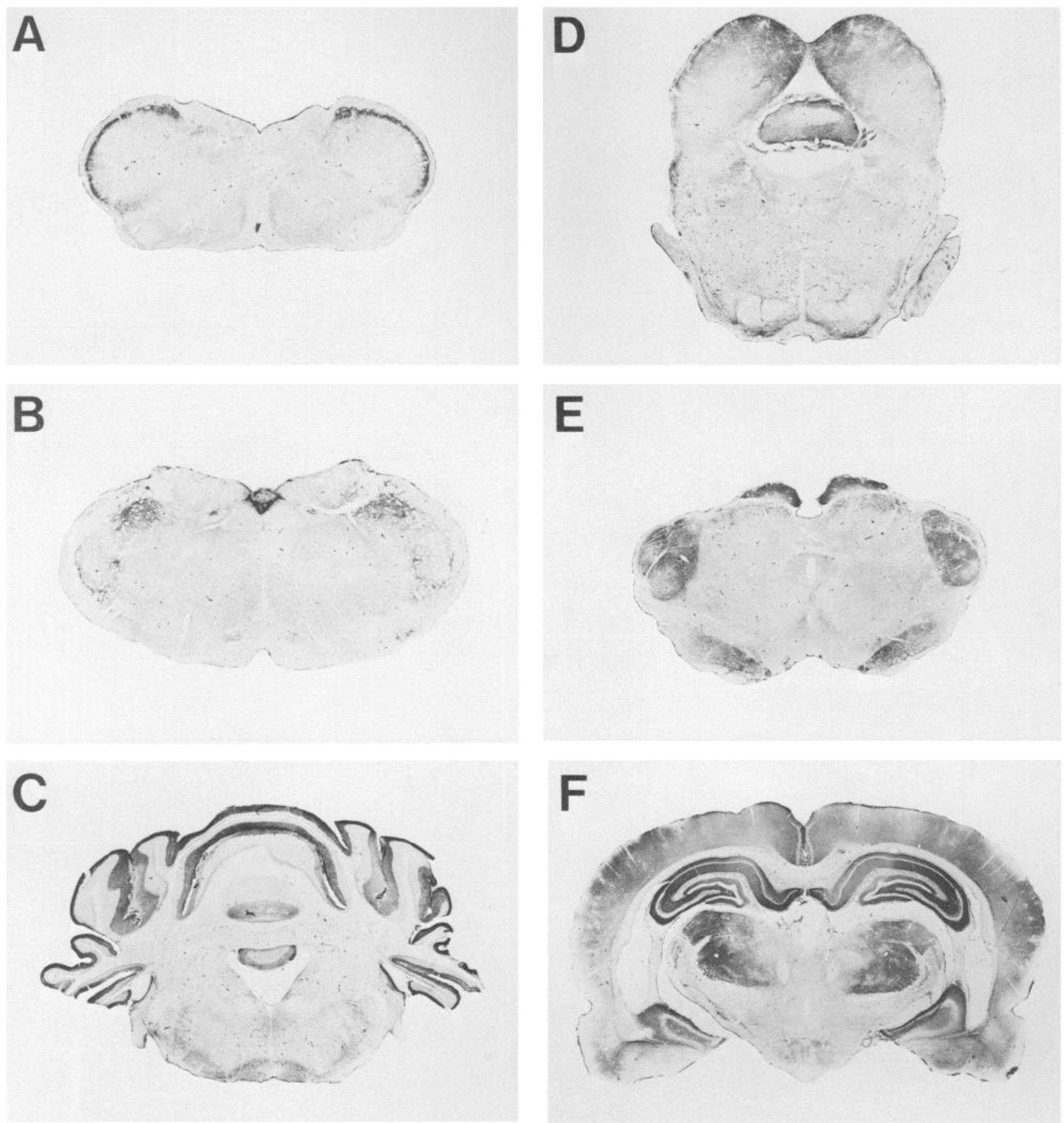

Figure 3. A, Immunocytochemical staining of rat brain with S-7B8 antibody produces dense labeling of nerve terminals in selected brain regions including: $A$ and $B$, spinal trigeminal nucleus; $C$, molecular layer of the cerebellum, $D$, inferior colliculus; $E$, superior colliculus (superficial laminae), medial geniculate, and dorsal lateral geniculate nuclei, and substantia nigra; and $F$, the ventrobasal thalamus and portions of the cerebral cortex. The hippocampus exhibits a striking laminar pattern of staining.

examination of spinal cord sections stained with S-7B8 antibody, electron microscopic analysis reveals numerous labeled profiles in laminae I and II of the spinal cord dorsal horn. These are scattered among many unlabeled profiles. The S-7B8-positive structures are nerve terminals of varying size, and the reaction product appears to be primarily associated with 40-50 $\mathrm{nm}$ spherical vesicles in the labeled terminals (Fig. 4). In some cases, the reaction product is also associated with the inner surface of the nerve terminal plasma membrane, or with mitochondrial membranes (Fig. $4 A$ ). The larger terminals exhibiting S-7B8 immunoreactivity (Fig. $4 A$ ) appear to correspond to the central terminals of primary afferents described previously by others (Ralston, 1979; Riberio-da-Silva and Coimbra, 1982). Stained terminals are often observed in close apposition to or making synaptic contact with unstained dendritic processes (Fig. 4, $A-C)$.

Within lamina II, staining with the S-7B8 antibody is also observed in some small-sized $(0.2 \mu \mathrm{m})$, round vesicle-containing structures which occur in bundles outside of synaptic zones (Fig. $4 D$ ). These structures may correspond to "axon fields" described previously in lamina II, which are comprised of bundles of unmyelinated axons (Ralston, 1968, 1979; Riberio-da-Silva and 

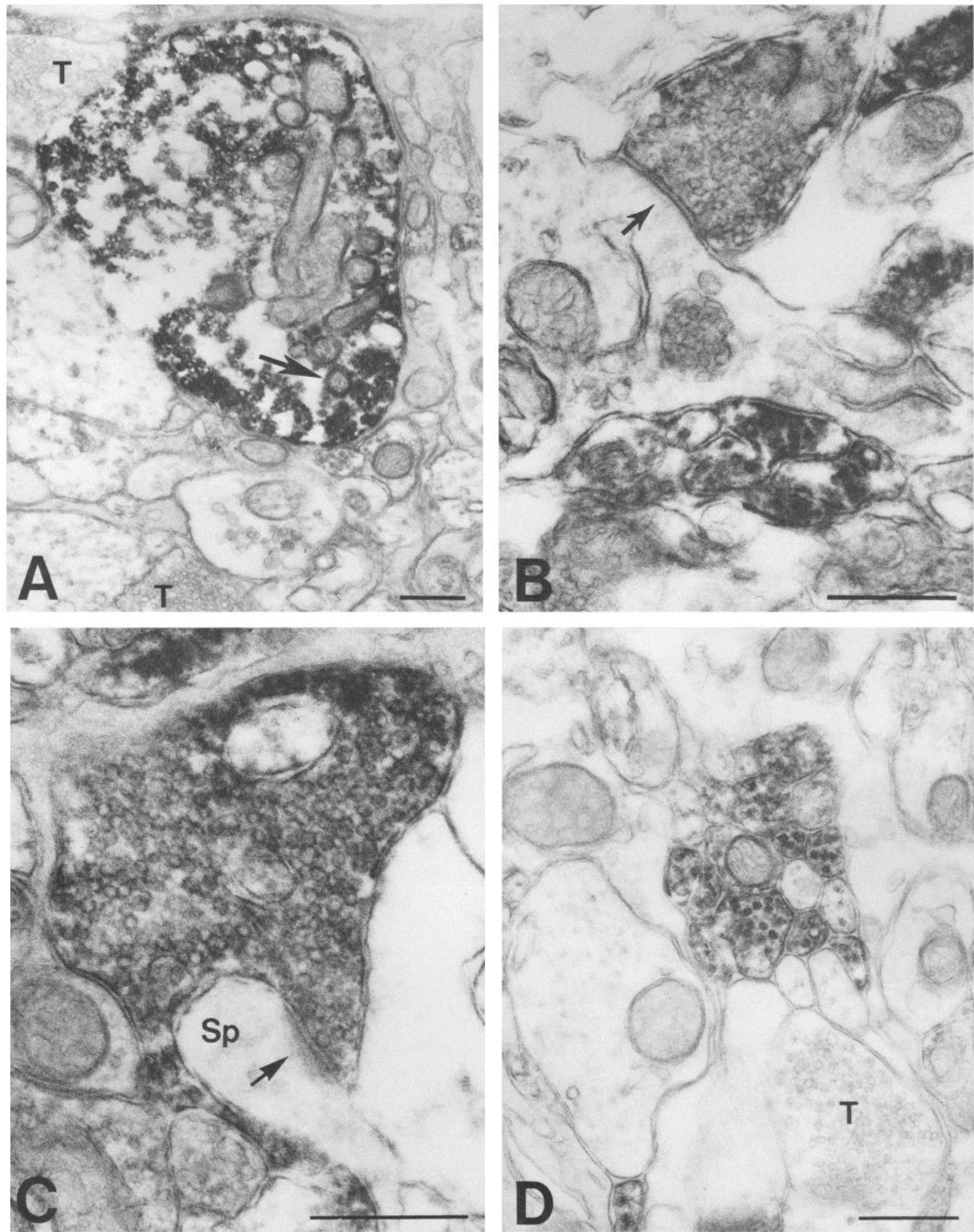

Figure 4. Electron micrographs depicting S-7B8 immunoreactivity in the superficial dorsal horn of rat lumbar spinal cord. $A$, Large nerve terminal exhibiting staining associated with synaptic vesicles. Reaction product is sometimes seen in association with mitochondrial outer membranes (arrow) or with the inner surface of the plasma membrane of the nerve terminal. Unlabeled terminals $(T)$ are also evident. $B$, Stained nerve terminal making synaptic contact (arrow) on a dendrite. $C$, Stained terminal making synaptic contact (arrow) with a dendritic spine ( $S p$ ). Synaptic vesicle membranes are densely stained. $D$, Staining localized to vesicular structures within bundles of small profiles tentatively identified as unmyelinated fibers ("axon fields"). Scale bar, $0.5 \mu \mathrm{m}$. 


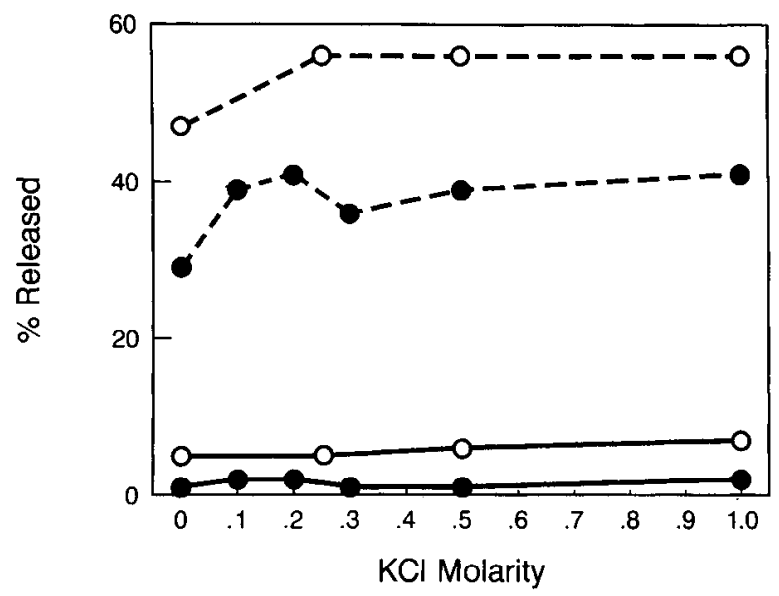

Figure 5. Percentage of the S-7B8 antigen (solid lines) and the total protein (broken lines) released from synaptosomal membranes by high ionic strength. Lyophilized synaptosomes were homogenized in $10 \mathrm{~mm}$ Tris buffer, $\mathrm{pH} 7.5$ (solid circles) or $\mathrm{pH} 8.5$ (open circles) containing 0$1.0 \mathrm{M} \mathrm{KCl}$. After incubation for $2 \mathrm{hr}$ at $4^{\circ} \mathrm{C}$, the samples were centrifuged at $115,000 \times g$ for $2 \mathrm{hr}$. The protein content of the pellets and supernatants was assayed (Bradford, 1976), and the S-7B8 antigen was analyzed on the dot-immunobinding assay. Values averaged from 2 experiments were plotted.

Coimbra, 1982). These "axon fields" contained both labeled and unlabeled profiles. In a few instances, staining is also observed within small-caliber myelinated axons.

Profiles not observed to stain with the S-7B8 antibody include neuronal cell bodies, flattened vesicle-containing terminals, dendrites, and glial elements.

\section{Antigen characterization}

To characterize the antigen recognized by the S-7B8 antibody, initial studies involved repeated extraction of synaptosomes with chloroform/methanol. This treatment, which should solubilize membrane lipids and proteolipids (Gombos and Zanetta, 1977), does not extract the S-7B8 antigen, which remains in the insoluble pellet. Next, the effect of a proteolytic enzyme was evaluated. Digestion of synaptosomes with trypsin diminishes the specific activity of the S-7B8 antigen, with losses approaching $90 \%$, at a trypsin to synaptosomal protein ratio of $1: 2$. Synaptosomes treated with trypsin plus a specific trypsin inhibitor

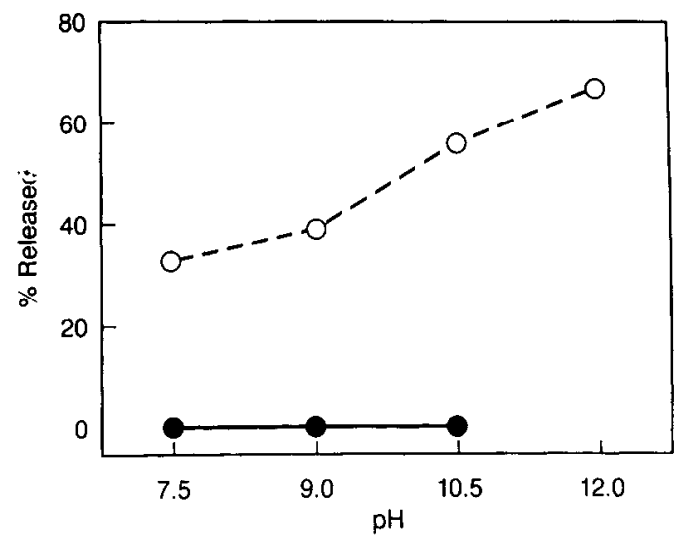

Figure 6. Percentage of the S-7B8 antigen (solid line) and total protein (broken line) released from synaptosomal membranes by alkaline $\mathrm{pH}$. Lyophilized synaptosomes were homogenized in $10 \mathrm{~mm}$ Tris buffer, $\mathrm{pH}$ 7.5. Aliquots of the suspension were adjusted to $\mathrm{pH} 8.5-9,10.5-10.8$, or $11.9-12.0$ by the addition of $\mathrm{NaOH}$ and centrifuged at $115,000 \times g$ for $2 \mathrm{hr}$. The resuspended pellets and the supernatants were adjusted to $\mathrm{pH} 7.5$ prior to analysis of protein content (Bradford, 1976) and S-7B8 antigen on the dot-immunobinding assay. Average values from 3 experiments are graphed. Note that at $\mathrm{pH} 12.0 \mathrm{~S}-7 \mathrm{~B} 8$ antigen cannot be detected in either the pellet (retained fraction) or the supernatant (released fraction).

retain up to $80 \%$ of the S-7B8 specific activity, at a ratio of trypsin to trypsin inhibitor of $1: 2$ to $1: 3$. These results suggest that the S-7B8 antigen is a protein.

The S-7B8 antigen is not readily solubilized from synaptosomal membranes and is thus likely to be an integral membrane component. Greater than $90 \%$ of the S-7B8 antigen is retained in the insoluble pellets after extraction of synaptosomes with $1.0 \mathrm{M} \mathrm{NaCl}$ or with $\mathrm{KCl}$ at concentrations ranging from 0.1 to $1.0 \mathrm{M}$, at pH 7.5 or 8.5 (Fig. 5). Similarly, extraction of synaptosomes with buffers up to $\mathrm{pH} 10.5$ does not release the S- $7 \mathrm{~B} 8$ antigen from the membranes, although greater than $50 \%$ of the total synaptosomal protein is released at this $\mathrm{pH}$ (Fig. 6). It was not possible to dctcrmine whether higher $\mathrm{pH}$ releases the S-7B8 antigen since exposure of synaptosomes to $\mathrm{pH}$ above 11.0 abolishes S-7B8 immunoreactivity in the fractions. Although high ionic strength or high $\mathrm{pH}$ do not solubilize the S-7B8 antigen from synaptosomal membranes, several nonionic and zwitterionic detergents $(0.5-1.0 \%$ Triton X-100, 35-40 mM

Table 1. Partial purification of the S-7B8 antigen

\begin{tabular}{lllllc} 
Sample & $\begin{array}{l}\text { Protein } \\
(\mu \mathrm{g})\end{array}$ & $\begin{array}{l}\text { Protein } \\
\text { yield (\%) }\end{array}$ & Antigen units & $\begin{array}{l}\text { Antigen } \\
\text { yield (\%) }\end{array}$ & $\begin{array}{c}\text { Specific } \\
\text { activity }\end{array}$ \\
\hline $\begin{array}{l}\text { Synaptosomes } \\
\text { "Alkaline-stripped" }\end{array}$ & 235,600 & 100.0 & 235,600 & 100.0 & 1.0 \\
$\quad \begin{array}{l}\text { synaptosomes } \\
\text { CHAPS soluble fraction }\end{array}$ & 124,000 & 52.6 & 223,200 & 94.7 & 1.8 \\
$\begin{array}{l}\text { Hydroxylapatite } \\
\quad \text { fractions (37-59) }\end{array}$ & 39,060 & 16.6 & 42,966 & 18.2 & $1.1^{*}$ \\
$\begin{array}{l}\text { Ion-exchange fractions } \\
\quad(12-14)\end{array}$ & 11,210 & 4.8 & 28,025 & 11.9 & $2.5^{*}$ \\
& 217 & 0.09 & 22,091 & 9.4 & $101.8^{*}$
\end{tabular}

The specific activity of the S-7B 8 antigen in various samples relative to that in synaptosomes was determined by densitometric analysis of dot-immunobinding assays. Asterisks $\left(^{*}\right)$ denote values for samples requiring TCA to precipitate proteins out of detergent solution, which diminishes S-7B8 activity. Antigen units were derived from the specific activity times the total protein. The yield of total protein and of the S-7B8 antigen are expressed relative to the amounts in the starting material, synaptosomes prepared from whole rat brain. Values shown are the results from the same experiment illustrated in Figures 7 and 8. 
Figure 7. Ion-exchange chromatography of the S-7B8 antigen. Hydroxylapatite column fractions $37-59$ enriched in the S-7B8 antigen were pooled and applied directly to a DEAE-Sepharose CL-6B column. S-7B8 specific activity (antigen units $/ \mu \mathrm{g}$ protein) and total protein in the fractions eluted from the DEAE column by a linear gradient of $\mathrm{NaCl}(150-450 \mathrm{~mm})$ are plotted. Fractions 12-14 have S-7B8 specific activity about 100 times that of the starting material (synaptosomes).

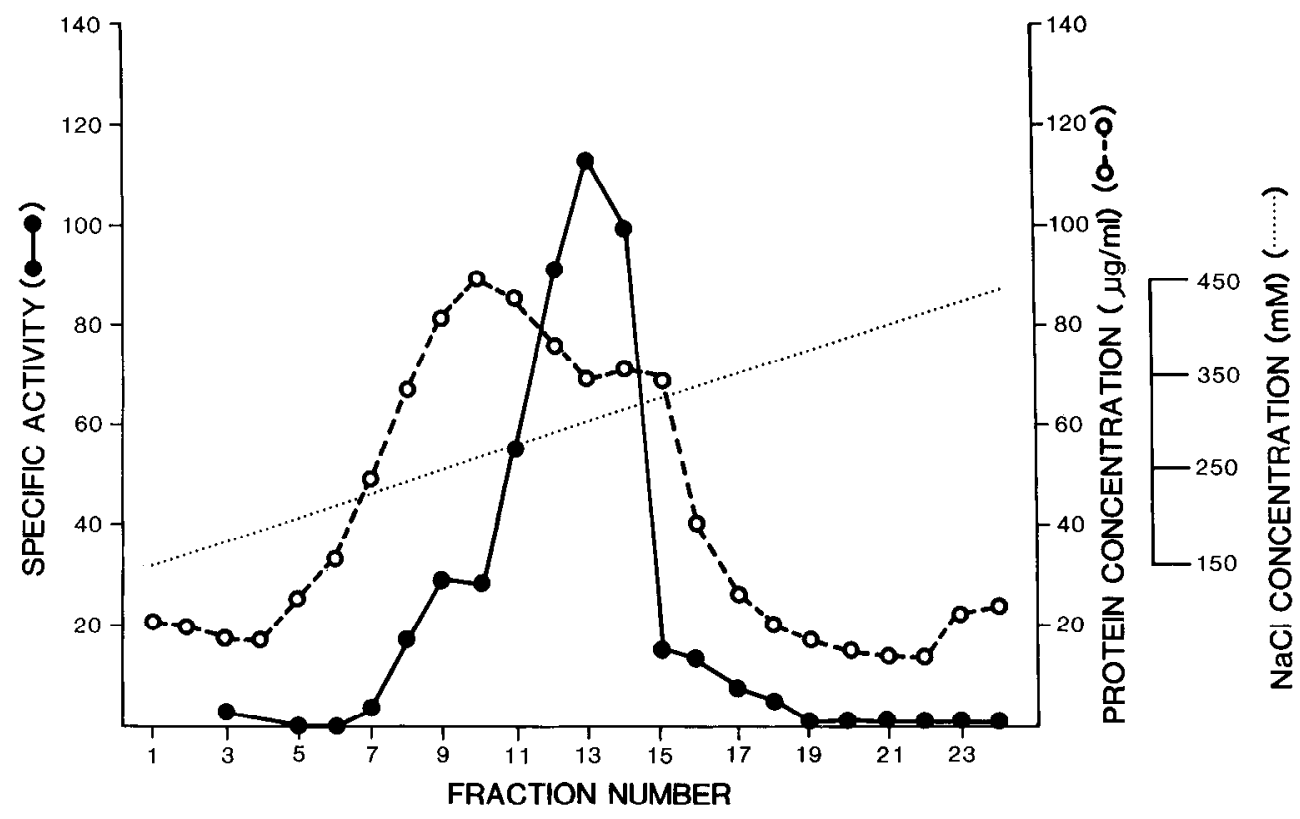

n-octyl-glucoside, 8-16 mm CHAPS) were found to be effective solubilization agents (see below).

Initial efforts to identify the molecular weight of the S-7B8 antigen using SDS-PAGE and Western blotting of synaptosomal proteins were unsuccessful. No detectable S-7B8 activity was present among the blotted proteins. Analysis on the dot-immunobinding assay indicated that exposure of synaptosomes to SDS-PAGE sample buffer (containing $2 \%$ SDS, with or without 5\% 2-mercaptoethanol) markedly reduces the S-7B8 activity. Various methods to renature proteins during the electrophoresis and blotting procedure (e.g., Mandrell and Zollinger, 1984) or the use of nondenaturing gel systems also proved unsatisfactory. Therefore, experiments were undertaken to partially purify the S-7B8 antigen using column chromatography.

In order to obtain samples enriched in S-7B8 antigen, detergent-solubilizcd ncuronal mcmbranc protcins wcre fractionated by chromatography on hydroxylapatite, and then on DEAE. The methods were first developed using a crude particulate fraction from rat brain as starting material because the yield of total protein in this fraction was much greater than that of purified synaptosomes. The high-speed centrifugation used to prepare the particulate fraction $(160,000 \times g)$ is sufficient to pellet synaptic vesicles released during the homogenization (Jahn et al., 1985), and this preparation has good activity for the S-7B8 antibody and for anti-synaptophysin. The experiments were then repeated using synaptosomes. The characteristics of binding to and elution from the 2 columns, as well as the apparent molecular weight of the S-7B8 antigen obtained from the 2 membrane preparations were essentially identical.

As described in Materials and Methods, rat brain synaptosomes or particulate fraction were first washed with alkaline $\mathrm{pH}$ buffer to produce an "alkaline-stripped" membrane preparation (see Fig. 6). The "alkaline-stripped" membrane pellet was then homogenized in CHAPS, and the soluble fraction was recovered after centrifugation. CHAPS (16 mM) was typically found to solubilize $65 \%$ of the total protein and $95 \%$ of the S-7B 8 antigen in the "alkaline-stripped" membrane fractions. The CHAPSsolubilized proteins were then chromatographed on hydroxyl- apatite. Approximately $40-50 \%$ of the total protein applied to the hydroxylapatite column appears in the unbound fraction under the conditions utilized. Bound proteins, including the S-7B8 antigen, were eluted from the column with a gradient of $75-175 \mathrm{~mm}$ sodium phosphate, and the gradient fractions were analyzed for S-7B8 antigen on the dot-immunobinding assay. Fractions enriched in the S-7B8 antigen elute from the hydroxylapatite column between 125 and $175 \mathrm{~mm}$ PB (fractions 3759) and exhibit apparent specific activity about 2.5 times that of synaptosomes (Table 1).

To determine the S-7B8 specific activity in the column fractions, TCA precipitation was used to facilitate binding of the proteins to nitrocellulose paper in the presence of $16 \mathrm{mM}$ CHAPS. This allowed rapid analysis of the S-7B8 activity in the fractions without removal of the detergent, which inhibits binding of proteins to nitrocellulose. It should be noted that even brief exposure of the proteins to TCA diminished the S-7B8 activity. However, the assay was sufficient to identify fractions enriched in the S-7B8 antigen, although the S-7B8 specific activity is underestimated (see Table 1).

The hydroxylapatite gradient fractions enriched in the S-7B8 antigen were pooled and applied directly to a DEAE-Sepharose CL-6B column. The S-7B8 antigen binds to the anion-exchange resin under the conditions used, whereas approximately $50 \%$ of the applied protein appears in the unbound fraction. The S-7B8 antigen elutes from the column between 275 and $325 \mathrm{~mm} \mathrm{NaCl}$, with peak specific activity about 100 times that of synaptosomes concentrated in 3 gradient fractions (fractions 12-14). Figure 7 illustrates the elution of total bound protein and the S-7B8 antigen from the anion-exchange column with the salt gradient. Table 1 shows the enrichment in the S-7B8-specific activity achieved at each step in the purification scheme.

The enriched fractions obtained after sequential chromatography over the 2 columns were then separated on SDS-PAGE and blotted to nitrocellulose. As illustrated in Figures 8 and 9, the S-7B8 antibody stains a band migrating with an $M_{r}$ of approximately $75,000 \mathrm{Da}$, under both reducing and nonreducing conditions. This protein has been designated NT75. Including 

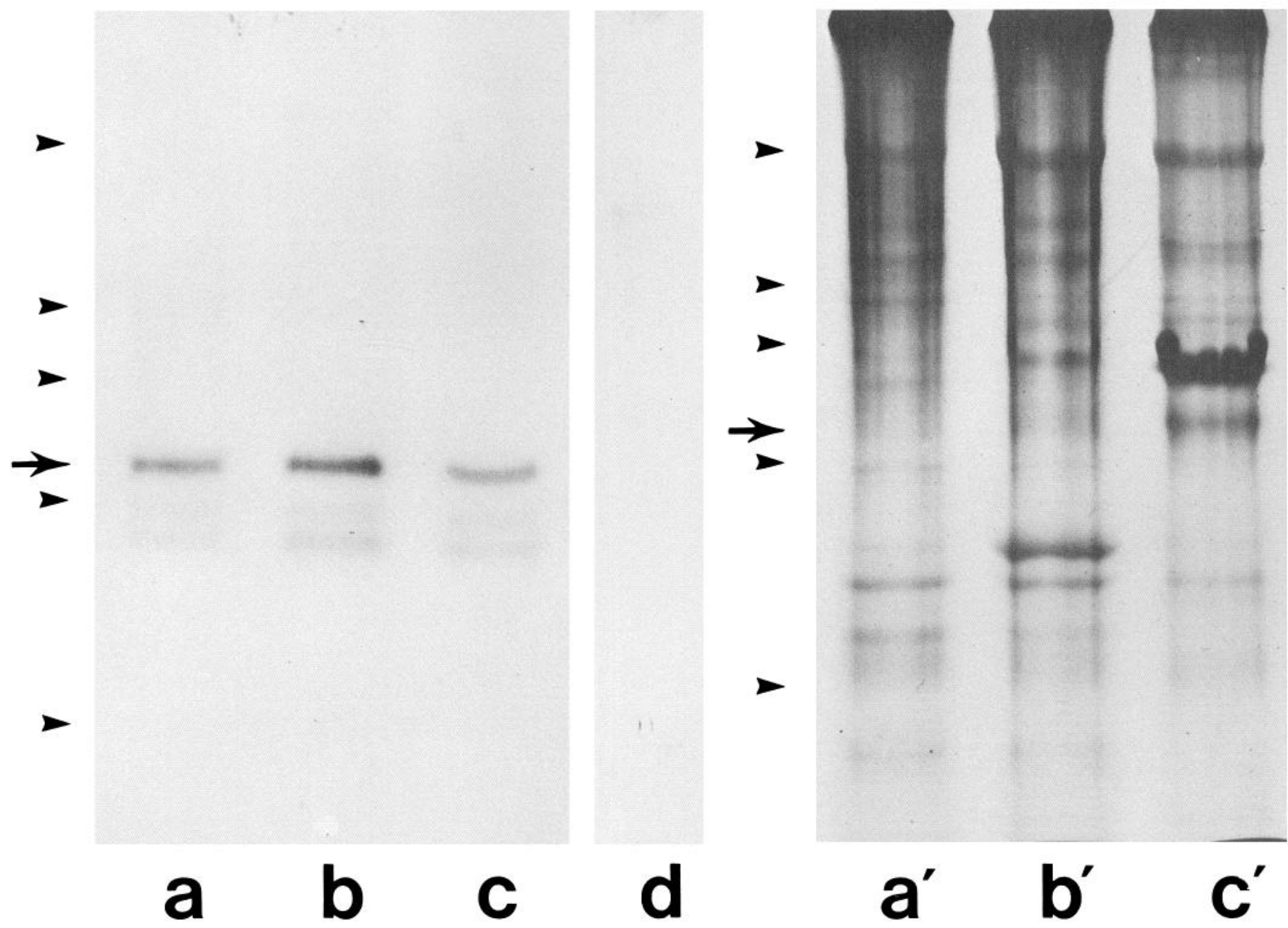

Figure 8. Identification of the S-7B8 antigen on immunoblots of enriched fractions generated by sequential chromatography of synaptosomal proteins on hydroxylapatite and DEAE-Sepharose. Lyophilized fractions were raised in sample buffer ( $2 \%$ SDS, $10 \%$ glycerol, and $0.67 \mathrm{M}$ Tris$\mathrm{HCl}$ ), without reducing agent, heated at $40^{\circ} \mathrm{C}$ for $10 \mathrm{~min}$, then subjected to SDS PAGE on $7.5 \%$ minigels and blotted to nitrocellulose. Lanes correspond to enriched gradient fractions obtained from the DEAE column as follows: $a$ and $a^{\prime}$, pooled fractions 10 and $11 ; b, b^{\prime}$, and $d$, pooled fractions 12 and 13; $c$ and $c^{\prime}$, pooled fractions 14 and 15. Nitrocellulose blots in lanes $a-c$ were stained with the S-7B8 antibody, and in lane $d$ with purified nonimmune mouse IgG. Lanes $a^{\prime}-c^{\prime}$ are the corresponding SDS-PAGE gels stained for protein with Coomassie blue. Lanes $a^{\prime}-c^{\prime}$ were loaded with approximately twice the amount of protein $(60 \mu \mathrm{g})$ as were the lanes blotted and stained with antibodies (30 $\mu \mathrm{g})$. Small arrowheads indicate the position of the molecular-mass standards: myosin $(200,000), \beta$-galactosidase $(116,250)$, phosphorylase B $(97,400)$, BSA $(66,200)$, and ovalbumin $(42,699)$. Large arrows point to the position of the S-7B8 antigen, a protein of $M_{r} 75,000$.

reducing agent (5\% 2-mercaptoethanol) in the electrophoresis sample buffer markedly diminishes S-7B8 immunoreactivity, but it does not alter the $M_{r}$ of the stained band (Fig. 9). Two additional bands exhibit light staining when the fractions having highest S-7B8 activity are electrophoresed under nonreducing conditions, the optimal conditions for demonstrating S-7B8 staining on immunoblots. These proteins, with apparent $M_{r}$ of 62,000 and $58,000 \mathrm{Da}$, may be proteolytic cleavage products of the 75,000 Da protein.

On Coomassie blue- or silver-stained SDS-PAGE gels of the same enriched fractions (Fig. 8, lanes $a^{\prime}-c^{\prime}$ ) there is little detectable protein in the 75,000 Da region, even when the gel lanes are loaded with excess protein. Densitometric scans indicate that the protein in the 70,000-80,000 Da area of the Coomassiestained gels accounts for no more than $1-2 \%$ of the total protein. Thus, the NT75 protein is a minor component of these fractions despite at least 100-fold enrichment in S-7B8 specific activity over the starting material (synaptosomes).

\section{Discussion}

The S-7B8 monoclonal antibody has been shown by immunocytochemistry to localize selectively to nerve terminals of restricted populations of neurons in the spinal cord and brain. This antibody was generated using rat brain synaptosomes as immunogen, in an attempt to identify molecules associated with specific populations of presynaptic terminals. Of 21 monoclonal antibodies evaluated by immunocytochemistry, the majority appeared to stain virtually all nerve terminals (Ritchie et al., 1986a). The S-7B8 antibody was chosen for further study because it exhibits the highest degree of selectivity for certain presynaptic endings. Subsequently, the antibody has been used in immunochemical studies to identify and partially purify its antigen, a 75,000 Da protein. This protein has been designated NT75.

NT75 was identified as the S-7B8 antigen on immunoblots of enriched fractions generated by sequential column chroma- 
Figure 9. Immunoblots of the S-7B8 antigen after SDS-PAGE under reducing and nonreducing conditions. Enriched fractions produced from a rat brain particulate fraction by doublecolumn chromatography as described were applied to the gels as follows: lane $a$, sample solubilized in buffer containing $2 \%$ SDS, $10 \%$ glycerol, and 0.067 м Tris- $\mathrm{HCl}, \mathrm{pH} 6.8$, and heated at $40^{\circ} \mathrm{C}$ for $10 \mathrm{~min}$; lane $b$, sample solubilized in buffer as in $a$, but also containing 5\% 2-mercaptoethanol, and heated at $40^{\circ} \mathrm{C}$ for $10 \mathrm{~min}$; and lane $c$, sample solubilized in buffer as in $b$, and boiled for 3 $\mathrm{min}$. All samples were electrophoresed on $7.5 \%$ minigels, transferred to nitrocellulose, and stained with the S-7B 8 antibody. Large arrows indicate the position of the S-7B8 antigen, NT75. Molecular-mass standards are the same as those in Figure 8. The addition of reducing agent and boiling of the samples results in diminished S-7B8 activity on the blots, but all detectable activity remains at a position of $75,000 \mathrm{Da}$.
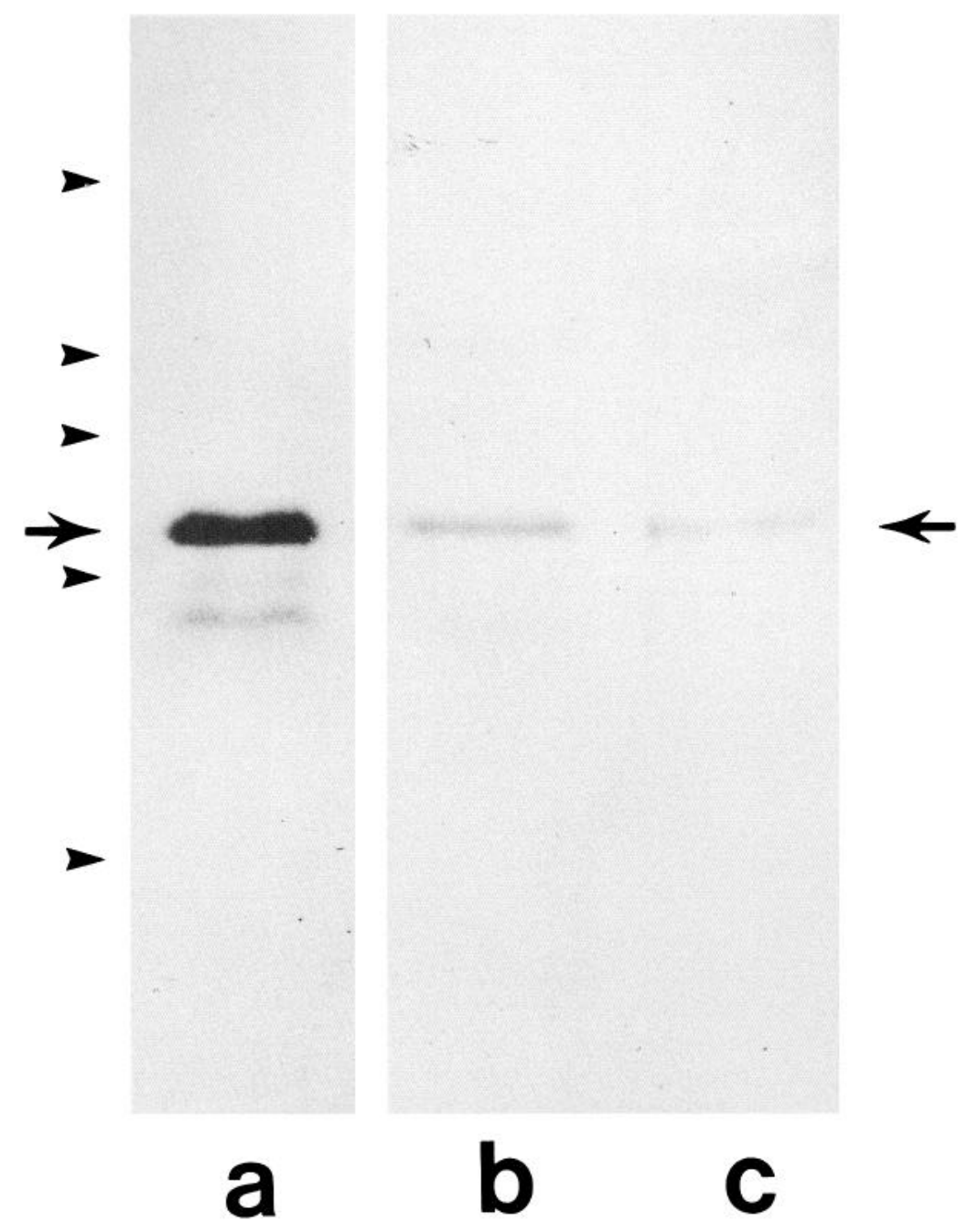

tography of synaptosomal membrane proteins. Two additional lower-molecular-weight bands, with $M_{r}$ of 62,000 and 58,000 $\mathrm{Da}$, were lightly stained on the immunoblots. That these bands may be proteolytic fragments of the $75,000 \mathrm{Da}$ protein is suggested by the observation that the ratio of these proteins to the $75,000 \mathrm{Da}$ band is variable between experiments. Alternatively, the lower molecular-weight proteins may be distinct polypeptides that copurify with NT75 and contain the S-7B8 epitope. When electrophoresis is carried out under reducing conditions, staining of the $75,000 \mathrm{Da}$ band is markedly reduced, and no other stained bands are evident. The effect of the reducing agent suggests that breaking disulfide bonds disrupts the S-7B8 epitope. In this context, a number of treatments known to denature proteins, including exposure to high $\mathrm{pH}$, SDS, and boiling, diminish or abolish binding activity of the S-7B8 antibody, indicating that the epitope is dependent on the folded structure of the NT75 protein.

The localization of the NT75 protein to nerve terminals was indicated by immunocytochemical staining with the S-7B8 antibody. Cell bodies of neurons known to contain NT75 in their endings do not exhibit detectable staining, unless colchicine is applied to block axonal transport. The lack of staining in cell bodies most likely reflects a low concentration of NT75 in this compartment and suggests that NT75 is routed directly and exclusively for axonal transport to the nerve terminals. Thus, NT75 appears similar to other nerve terminal membrane proteins that are routed for fast anterograde axonal transport (Baitinger et al., 1982).

The most striking feature of immunocytochemical localization of the NT75 protein is its selective association with subpopulations of nerve terminals. While the precise identification of all neuronal populations containing the NT75 protein is incomplete, it appears that many neurons comprising the sensory systems of the brain and spinal cord contain the NT75 protein. However, the S-7B8 antibody also localizes to nerve terminals in the substantia nigra, hippocampus, cerebellar cortex, and other CNS structures which are not generally considered components of "sensory" systems. Based upon the immunocytochemical staining pattern, it is not obvious what attribute or function might be shared by neurons containing the NT75 protein. It is of interest, however, that an essentially similar pattern of immunocytochemical staining reported here in the rat is also present in chicken and monkey (unpublished observations). This suggests that the NT75 protein, as well as its pattern of selective distribution, is highly conserved in evolution.

The pattern of the distribution of NT75, as well as characteristics of the molecule, allow for comparisons with other known nerve terminal proteins. A major class of nerve terminal pro- 
teins with selective distributions are those related to the synthesis, storage, uptake, or metabolism of neurotransmitters. However, it appears unlikely that NT75 is related to the neurotransmitter specificity of the neurons in which it is found. In brain, the pattern of S-7B8 immunoreactivity does not correlate with the localization of any known neurotransmitler or neurotransmitter-related substance. Although the nerve terminals of many pathways that may use excitatory amino acids (glutamate/aspartate) appear to stain with the S-7B8 antibody, NT75 does not correspond in molecular weight or cellular distribution to any of the enzymes involved in amino acid metabolism (Graybiel and Ragsdale, 1983; Ottersen and Storm-Mathisen, 1984). In the spinal cord, the S-7B8-positive terminals are mainly those of primary sensory neurons projecting to the superficial dorsal horn. The candidate transmitters of primary afferents include various neuropeptides, excitatory amino acids, nucleotides, and the monoamines serotonin and dopamine (see Hunt, 1983; Jessell and Dodd, 1986). The S-7B8 immunocytochemical staining in the spinal dorsal horn does not match the pattern of any single subpopulation of afferent terminals containing these putative transmitter substances. This reinforces the view that those nerve terminals containing NT75 are heterogeneous with respect to transmitter phenotype.

Components of certain second-messenger and protein phosphorylation systems are known to be constituents of nerve terminals, and to be selectively distributed in different populations of nerve cells. Of the components that have been mapped in brain, the localization of protein kinase $C$, as revealed by phorbol ester binding, seems to correspond most closely to the distribution of NT75 (Worley et al., 1986a, b). Also, the reported molecular weight of protein kinase C, 77-82 KDa (Kikkawa et al., 1982; Girard et al., 1985), approximates that determined for NT75. However, NT75, in the neural systems examined so far, is concentrated in nerve terminals, whereas protein kinase $C$ has a wider distribution, being associated with certain myelinated fiber tracts, and with dendrites, cell bodies, and cell nuclei of several neuronal populations (Girard et al., 1985, 1986; Worley et al., 1986a, b; Saito ct al., 1988). In addition, protein kinase $\mathrm{C}$ is found in organs and tissues that do not exhibit S-7B8 immunoreactivity (Kuo et al., 1980). Although the distribution of each of the different subspecies of protein kinase $\mathrm{C}$ have not been fully studied (see Saito et al., 1988), it appears unlikely that NT75 corresponds to protein kinase C or to any other known component of the protein phosphorylation systems described to date.

The immunoelectron microscopy studies suggest that NT75 may be associated with synaptic vesicle membranes, and possibly the cytoplasmic face of the nerve terminal plasma membrane. This localization agrees with results indicating that NT75 may be an integral membrane component. However, this interpretation of the staining in immunoreactive nerve terminals will need to be confirmed with higher resolution techniques, since diffusion of the $\mathrm{DAB}$ reaction product can produce artifact. It was not possible to resolve whether S-7B8 immunoreactivity appears in the presynaptic junctional membrane or the synaptic cleft, as might be expected for a synaptic vesicle component. It should also be noted that immunocytochemistry with the monoclonal antibody localizes only the portion of the NT75 protein containing the epitope, and thus a portion of the molecule could be exposed in the vesicle lumen or on the extracellular surface of the nerve terminal plasma membrane.

Several proteins associated with synaptic vesicles have re- cently been identified. Synapsin I, a peripheral membrane phosphoprotein doublet of $80,000-86,000 \mathrm{Da}$, is bound to the cytoplasmic surface of virtually all small synaptic vesicles in brain (De Camilli et al., 1983a, b; Huttner et al., 1983). Proteins of 65,000 Da (Matthew et al., 1981) and 38,000 Da (synaptophysin) (Jahn et al., 1985; Wiedenmann and Franke, 1985; Obata et al., 1986) have widespread distributions in both central and peripheral nervous system synaptic vesicles, and also occur in the secretory vesicles of endocrine cells (Lowe et al., 1988). A synaptic vesicle glycoprotein described by Buckley and Kelly (1985), with an $M_{r}$ of 75,000-85,000 Da in mammalian brain, exhibits a similar widespread distribution in neuronal and other secretory vesicles. Last, 2 phosphoproteins, IIIa and IIIb, of 74,000 and 55,000 $\mathrm{Da}$, have recently been shown to be associated with vesicles in neurons and cells of the adrenal medulla (Browning et al., 1987). NT75 does not appear to correspond to any of these previously characterized synaptic vesicle proteins on the basis of its apparent molecular weight, localization in selected nerve terminals, and lack of occurrence in endocrine (or other non-neuronal) cells.

Other proteins associated with nerve terminals and growth cones have been implicated in axonal growth, regeneration, and the formation of synaptic connections. In this group are the growth-associated proteins, or GAPS (Skene and Willard, 1981; Benowitz and Lewis, 1983; Meiri et al., 1986; Skene et al., 1986; Gorgels et al., 1987; Neve et al., 1987). GAP-43 occurs in selected nerve terminals in adult nervous system, although it is best known for the highly elevated levels occurring in developing and regenerating axons and growth cones (Oestreicher and Gispen, 1986; Benowitz et al., 1988). Analysis of S-7B8 immunoreactivity in developing nervous system has shown that NT75 appears in growing fibers and becomes concentrated in the nerve terminals during synaptogenesis (Ritchie et al., 1986c; Cabalka et al., 1987, 1988; Wright et al., 1987). Like GAP-43, NT75 has recently been shown to occur at elevated levels in developing spinal cord as compared with the adult (Cabalka et al., 1987). Thus, NT75 shares certain characteristics with the class of nerve terminal components thought to have roles in development and regeneration. However, it must be recognized that whatever role the NT75 protein may have in developing nerve terminals, this function is restricted to certain populations of neurons and is maintained, at least in part, in the adult nervous system.

\section{References}

Axelrod, J., and I. J. Kopin (1969) The uptake, storage, release and metabolism of noradrenaline in sympathetic nerves. Prog. Brain Res. 31: $21-32$.

Baitinger, C., J. Levine, T. Loren, C. Simon, P. Skene, and M. Willard (1982) Characteristics of axonally transported proteins. In Axoplasmic Transport, D. G. Weiss, ed., pp. 110-120, Springer Verlag, New York.

Benowitz, L. I., and E. R. Lewis (1983) Increased transport of 4449,000 dalton acidic proteins during regeneration of the goldfish optic nerve: A 2-dimensional gel analysis. J. Neurosci. 3: 2153-2163.

Benowitz, L. I., and A. Routtenberg (1987) A membrane phosphoprotein associated with neural development, axonal regeneration, phospholipid metabolism, and synaptic plasticity. TINS 10:527-532.

Bcnowitz, L. I., P. J. Apostolides, N. Perrone-Bizzozero, S. P. Finklestein, and H. Zwiers (1988) Anatomical distribution of the growthassociated protein GAP-43/B-50 in the adult rat brain. J. Neurosci. 8: 339-352.

Bradford, M. M. (1976) A rapid and sensitive method for the quantitation of microgram quantities of protein using the principle of protein dye binding. Anal. Biochem. 72: 248-254.

Browning, M. D., C.-K. Huang, and P. Greengard (1987) Similarities 
between protein IIIa and protein IIIb, two prominent synaptic vesicleassociated phosphoproteins. J. Neurosci. 7: 847-853.

Buckley, K. M., and R. B. Kelly (1985) Identification of a transmembrane glycoprotein specific for secretory vesicles of neural and endocrine cells. J. Cell Biol. 100: 1284-1294.

Cabalka, L. M., T. C. Ritchie, M. A. Thomas, and J. D. Coulter (1987) Expression of a unique nerve terminal protein during spinal cord development. Soc. Neurosci. Abstr. 13: 1427.

Cabalka, L. M., T. C. Ritchie, and J. D. Coulter (1988) Localization of the S-7B8 antigen during synaptogensis. Soc. Neurosci. Abstr. 14: 731.

Carlson, S. S., P. Caroni, and R. B. Kelly (1986) A nerve terminal anchorage protein from electric organ. J. Cell Biol. 103: 509-520.

De Camilli, P., R. Cameron, and P. Greengard (1983a) Synapsin I (protein I), a nerve terminal-specific phosphoprotein, I. Its general distribution in synapses of the central and peripheral nervous system demonstrated by immunofluorescence on frozen and plastic sections. J. Cell Biol. 96: 1337-1354.

De Camilli, P., S. M. Harris, Jr., W. B. Huttner, and P. Greengard (1983b) Synapsin I (protein I), a nerve terminal-specific phosphoprotein. II. Its specific association with synaptic vesicles demonstrated by immunocytochemistry in agarose-embedded synaptosomes. J. Cell Biol. 96: 1355-1373.

Dodd, J., D. Solter, and T. M. Jessell (1984) Monoclonal antibodies against carbohydrate differentiation antigens identify subsets of primary sensory neurones. Nature 311: 469-472.

Ellis, L., I. Wallis, E. Abreu, and K. H. Pfenninger (1985) Nerve growth cones isolated from fetal rat brain. IV. Preparation of a membrane subfraction and identification of a membrane glycoprotein expressed on sprouting neurons. J. Cell Biol. 101: 1977-1989.

Girard, P. R., G. J. Mazzei, J. G. Wood, and J. F. Kuo (1985) Polyclonal antibodies to phospholipid/ $\mathrm{Ca}^{2+}$-dependent protein kinase and immunocytochemical localization of the enzyme in rat brain. Proc. Natl. Acad. Sci. USA 82: 3030-3034.

Girard, P. R., G. J. Mazzei, and J. F. Kuo (1986) Immunological quantitation of phospholipid/ $\mathrm{Ca}^{2+}$-dependent protein kinase and its fragments. J. Biol. Chem. 261: 370-375.

Gombos, G., and J. P. Zanetta (1977) Recent methods for the separation and analysis of nervous system glycoproteins. Res. Methods Neurochem. 4: 307-363.

Goodlett, C. R., T. C. Ritchie, D. J. Wright, J. D. Coulter, and J. R. West (1986) Lesion-induced changes in the pattern of organization of a synaptic vesicle protein in the dentate gyrus of the adult rat. Soc. Neurosci. Abstr. 12: 513.

Gorgels, T. G. M. F., A. B. Oestreicher, E. J. M. de Kort, and W. H. Gispen (1987) Immunocytochemical distribution of the protein kinase $\mathrm{C}$ substrate B-50 (GAP43) in developing rat pyramidal tract. Neurosci. Lett. 83: 59-64.

Gottlieb, D. I., and L. Glaser (1980) Cellular recognition during development. Annu. Rev. Neurosci. 3: 303-318.

Graybiel, A. M., and C. W. Ragsdale, Jr. (1983) Biochemical anatomy of the striatum. In Chemical Neuroanatomy, P. C. Emson, ed., pp. 427-504, Raven, New York.

Gurd, J. W., L. R. Jones, H. R. Mahler, and W. J. Moore (1974) Isolation and partial characterization of rat brain synaptic plasma membranes. J. Neurochem. 22: 281-290.

Hunt, S. P. (1983) Cytochemistry of the spinal cord. In Chemical Neuroanatomy, P. C. Emson, ed., pp. 53-84, Raven, New York.

Huttner, W. B., W. Schiebler, P. Greengard, and P. DeCamilli (1983) Synapsin I (Protein I), a nerve terminal-specific phosphoprotein. III. Its association with synaptic vesicles studied in a highly purified synaptic vesicle preparation. J. Cell Biol. 96: 1374-1388.

Jahn, R., W. Schicblcr, C. Ouimet, and P. Greengard (1985) A 38,000dalton membrane protein (P38) present in synaptic vesicles. Proc. Natl. Acad. Sci. USA 82: 4137-4141.

Jessell, T. M., and J. Dodd (1986) Neurotransmitters and differentiation antigens in subsets of sensory neurons projecting to the spinal dorsal horn. In Neuropeptides in Neurologic and Psychiatric Disease, Vol. 64, Association for Research in Nervous and Mental Disease Research Publications, J. B. Martin and J. D. Barchas, eds., pp. 111133, Raven, New York.

Johnson, D. A., J. W. Gautsch, J. R. Sportsman, and J. H. Elder (1984) Improved technique utilizing nonfat dry milk for analysis of proteins and nucleic acids transferred to nitrocellulose. Gene Anal. Techn. 1: 3-8.
Kanekar, S. S., T. C. Ritchie, and I. D. Coulter (1986) A synaptic vesicle membrane protein associated with sensory nerve terminals in the spinal cord. Soc. Neurosci. Abstr. 12: 333.

Kelly, R. B., and J. B. Hooper (1982) Cholinergic vesicles. In The Secretory Granule, A. M. Poisner and J. M. Trifuro, eds., pp. 81118, Elsevier/North Holland Biomedical Press, Amsterdam.

Kelly, R. B., K. M. Buckley, T. L. Burgess, S. S. Carlson, P. Caroni, J. E. Hooper, A. Katzen, H. P. Moore, S. R. Pfeffer, and T. A. Schroer (1983) Membrane traffic in peptide-secreting cells. Cold Spring Harbor Symp. Quant. Biol. 48: 697-705.

Kennedy, M. (1985) New functions for synaptic vesicle proteins? TINS 8: 466-467.

Kennett, R. H., J. Denis, A. Tung, and N. Klinman (1978) Hybrid plasmacytoma production: Fusions with adult spleen cells, monoclonal spleen fragments, neonatal spleen cells and human spleen cells. Curr. Top. Microbiol. Immunol. 81: 77-91.

Kikkawa, U., Y. Takai, R. Minakuchi, S. Inohara, and Y. Nishizuka (1982) Calcium-activated, phospholipid-dependent protein kinase from rat brain. J. Biol. Chem. 257: 13341-13348.

Kuo, J. F., R. G. G. Andersson, B. C. Wise, L. Mackerlova, I. Salomonsson, N. L. Brackett, N. Katoh, M. Shoji, and R. W. Wrenn (1980) Calcium-dependent protein kinase: Widespread occurrence in various tissues and phyla of the animal kingdom and comparison of effects of phospholipid, calmodulin, and trifluoperazine. Proc. Natl. Acad. Sci. USA 77: 7039-7043.

Laemmli, U. K. (1970) Cleavage of structural proteins during the assembly of the head of bacteriophage T4. Nature 227: 680-685.

Lopez, L. C., E. M. Bayna, D. Litoff, N. L. Shaper, J. H. Shaper, and B. D. Shur (1985) Receptor function of mouse sperm surface galactosyltransferase during fertilization. J. Cell Biol. 101: 1501-1510.

Lowe, A. W., L. Madeddu, and R. B. Kelly (1988) Endocrine secretory granules and neuronal synaptic vesicles have three integral membrane proteins in common. J. Cell Biol. 106: 51-59.

Lowry, O. H., N. J. Rosebrough, A. L. Farr, and R. J. Randall (1951) Protein measurement with the folin phenol reagent. J. Biol. Chem. 193: 265-275.

Magill-Solc, C., and U. J. McMahan (1988) Motor neurons contain agrin-like molecules. J. Cell Biol. 107: 1825-1833.

Mandrell, R. E., and W. D. Zollinger (1984) Use of a Zwitterionic detergent for the restoration of the antibody-binding capacity of electroblotted meningococcal outer membrane proteins. J. Immunol. Methods 67: 1-11.

Markwell, M. A. K., S. M. Haas, L. L. Bieber, and N. E. Tolbert (1978) A modification of the Lowry procedure to simplify protein determination in membrane and lipoprotein samples. Anal. Biochem. 87: 206-210.

Matthew, W. D., L. Tsavaler, and L. F. Reichardt (1981) Identification of a synaptic vesicle-specific membrane protein with a wide distribution in neuronal and neurosecretory tissue. J. Cell Biol. 91: 257269.

Meiri, K. F., K. H. Pfenninger, and M. B. Willard (1986) Growthassociated protein, GAP-43, a polypeptide that is induced when neurons extend axons, is a component of growth cones and corresponds to pp46, a major polypeptide of a subcellular fraction enriched in growth cones. Proc. Natl. Acad. Sci. USA 83: 3537-3541.

Miller, R. J. (1985) Second messengers, phosphorylation and neurotransmitter release. TINS $8: 463-465$.

Neve, R. L., N. I. Perrone-Bizzozero, S. P. Finklestein, H. Zwiers, E. Bird, D. M. Kurnit, and L. I. Benowitz (1987) The neuronal growthassociated protein GAP-43 (B-50, F1): Neuronal specificity, developmental regulation and regional distribution of the human and rat mRNAs. Mol. Brain Res. 2: 177-183.

Obata, K., H. Nishiyc, S. C. Fujita, T. Shirao, H. Inouc, and K. Uchizono (1986) Identification of a synaptic vesicle-specific 38,000-Dalton protein by monoclonal antibodies. Brain Res. 375:37-48.

Oestreicher, A. B., and W. H. Gispen (1986) Comparison of the immunocytochemical distribution of the phosphoprotein B-50 in the cerebellum and hippocampus of immature and adult rat brain. Brain Res. 375: 267-279.

Ottersen, O. P., and J. Storm-Mathisen (1984) Neurons containing or accumulating transmitter amino acids. In Handbook of Chemical Neuroanatomy, Vol. 3, A. Bjorklund, T. Hökfelt, and M. J. Kuhar, eds., pp. 141-246, Elsevier/North Holland, Amsterdam.

Ouimet, C. C. T. L. McGuinness, and P. Greengard (1984) Immunocytochemical localization of calcium/calmodulin-dependent pro- 
tein kinase II in rat brain. Proc. Natl. Acad. Sci. USA 81 : 5604-5608.

Pickel, V. M., T. H. Joh, and D. J. Reis (1975) Ultrastructural localization of tyrosine hydroxylase in noradrenergic neurons of brain Proc. Natl. Acad. Sci. USA 72: 659-663.

Ralston, H. J. (1968) The fine structure of neurons in the dorsal horn of the macaque spinal cord. J. Comp. Neurol. 132: 275-302.

Ralston, H. J., III (1979) The fine structure of laminae I, II and III of the macaque spinal cord. J. Comp. Neurol. 184: 619-642.

Riberio-da-Silva, A., and A. Coimbra (1982) Two types of synaptic glomeruli and their distribution in laminae I-III of the rat spinal cord. J. Comp. Neurol. 209: 176-186.

Ritchie, T. C., R. H. Fabian, and J. D. Coulter (1985) Axonal transport of antibodies to subcellular and protein fractions of rat brain. Brain Res. 343: 252-261.

Ritchie, T. C., R. H. Fabian, J. V. A. Choate, and J. D. Coulter (1986a) Axonal transport of monoclonal antibodies. J. Neurosci. 6: $1177-$ 1184.

Ritchie, T. C., M. A. Thomas, C. L. Olson, S. S. Kanekar, and J. D. Coulter (1986b) A synaptic vesicle protein with a selective distribution in spinal cord and brain. Soc. Neurosci. Abstr. 12: 1500.

Ritchie, T. C., M. A. Thomas, S. S. Kanekar, D. J. Wright, and J. D. Coulter (1986c) A synaptic vesicle protein in selected populations of nerve terminals. J. Cell Biol. Abstr. 103: 76a.

Rosa, P., A. Hille, R. W. H. Lee, A. Zanini, P. De Camilli, and W. B. Huttner (1985) Secretogranins I and II: Two tyrosine-sulfated secretory proteins common to a variety of cells secreting peptides by the regulated pathway. J. Cell Biol. 101: 1999-2011.

Ruda, M. A., J. Coffield, and H. W. M. Steinbusch (1982) Immunocytochemical analysis of serotonergic axons in laminae I and II of the lumbar spinal cord of the cat. J. Neurosci. 2: 1660-1671.

Saito, N., U. Kikkawa, Y. Nishizuka, and C. Tanaka (1988) Distribution of protein-kinase $\mathrm{C}$-like immunoreactive neurons in rat brain. J. Neurosci. 8: 369-382.

Sanes, J. R., L. M. Marshall, and U. J. McMahan (1978) Reinnervation of muscle fiber basal lamina after removal of myofibers. J. Cell Biol. 78: 176-199.

Schachner, M., A. Faissner, J. Kruse, J. Linder, D. H. Meier, R. G. Rathjen, and H. Wernecke (1983) Cell type specificity and developmental expression of neural cell-surface components involved in cell interactions and of structurally related molecules. Cold Spring Harbor Symp. Quant. Biol. 48: 557-568.

Schwob, J. E., and D. I. Gottlieb (1988) Purification and characterization of an antigen that is spatially segregated in the primary olfactory projection. J. Neurosci. 8: 3470-3480.

Skene, J. H. P., and M. Willard (1981) Changes in axonally transported proteins during axon regeneration in toad retinal ganglion cells. $\mathrm{J}$. Cell Biol. 89: 86-95.
Skene, J. H. P., R. D. Jacobson, G. J. Snipes, C. B. McGuire, J. J. Norden, and J. A. Freeman (1986) A protein induced during nerve growth (GAP-43) is a major component of growth cone membranes. Science 233: 783-786.

Smith, S. J., and G. J. Augustine (1988) Calcium ions, active zones and synaptic transmitter release. TINS 11: 458-464.

Sperry, R. W. (1963) Chemoaffinity in the orderly growth of nerve fiber patterns and connections. Exp. Neurol. 7: 46-64.

Sternberger, L. A. (1978) The unlabeled antibody peroxidase antiperoxidase (PAP) method. In Immunocytochemistry, L. A. Sternberger ed., pp. 104-169, Wiley, New York.

Swanson, L. W., and B. K. Hartman (1975) The central adrenergic system. An immunofluorescence study of the location of cell bodies and their efferent connections in the rat utilizing dopamine- $\beta$-hydroxylase as a marker. J. Comp. Neurol. 163: 467-506.

Thiery, J. P., R. Brackenbury, U. Rutishauser, and G. Edelman (1977) Adhesion among neural cells of the chick embryo. II. Purification and characterization of a cell adhesion molecule from neural retina. J. Biol. Chem. 252: 6841-6845.

Towbin, H., T. Staehelin, and J. Gordon (1979) Electrophoretic transfer of proteins from polyacrylamide gels to nitrocellulose sheets: Procedures and some applications. Proc. Natl. Acad. Sci. USA 76:43504354.

Wainer, B. H., A. I. Levy, E. J. Mutson, and M.-M. Mesulam (1984) Cholinergic systems in mammalian brain identified with antibodies against choline acetyltransferase. Neurochem. Int. 6: 163-181.

Wallis, I., L. Ellis, K. Suh, and K. H. Pfenninger (1985) Immunolocalization of a neuronal growth-dependent membrane glycoprotein. J. Cell Biol. 101: 1990-1998.

Wiedenmann, B., and W. W. Franke (1985) Identification and localization of synaptophysin, an integral membrane glycoprotein of $\mathrm{Mr}$ 38,000 characteristic of presynaptic vesicles. Cell 41: 1017-1028.

Worley, P. F., J. M. Baraban, and S. H. Snyder (1986a) Heterogeneous localization of protein kinase $C$ in rat brain: Autoradiographic analysis of phorbol ester receptor binding. J. Neurosci. 6: 199-207.

Worley, P. F., J. M. Baraban, and S. H. Snyder (1986b) Mapping second messenger systems in the brain: Differential localizations of adenylate cyclase and protein kinase C. Proc. Natl. Acad. Sci. USA 83: 4053-4057.

Wright, D. J., T. C. Ritchie, and J. D. Coulter (1986) Selective distribution of a synaptic vesicle protein. Soc. Neurosci. Abstr. 12: 725 .

Wright, D. J., T. C. Ritchie, and J. D. Coulter (1987) Expression of a selectively distributed nerve terminal protein in cerebellar cortex. Soc. Neurosci. Abstr. 13: 1427. 